\title{
REDUCED POLLEN TUBE GROWTH AND THE PRESENCE OF CALLOSE IN THE PISTIL OF THE MALE FLORAL STAGE OF THE AVOCADO
}

\author{
M. SEDGLEY \\ CSIRO Division of Horticultural Research, Box 350, GPO, Adelaide, South Australia 5001 \\ (Australia)
}

(Received 25 January 1977)

\begin{abstract}
Sedgley, M., 1977. Reduced pollen tube growth and the presence of callose in the pistil of the male floral stage of the avocado. Scientia Hort., 7: 27-36.

Pollen tube growth was studied in the pistil of the male floral stage of the avocado. Selfpollination of the male stage occurred but pollen tubes did not reach the ovary. When female and male stages were hand pollinated, fewer pollen tubes were present in the pistil of the male than in the female stage. A tube reached the ovary in only 1 of 110 male stage pistils, as compared with all female stage pistils observed. Flowers pollinated in the female stage were retained on the plant for longer than flowers pollinated in the male stage.

Aniline blue-positive and resorcin blue-positive material (callose) was not present in the pistil of flowers in the female stage but occurred in $46 \%$ of the aniline blue-stained and $30 \%$ of the resorcin blue-stained pistils in the male floral stage. By $42 \mathrm{~h}$ after first opening, callose was present in every pistil observed, in association with the cell walls of the stigmatic papillae, the transmitting tissue, the vascular tissue or the cortex and epidermis or a combination of these tissues. Callose occured earlier in pollinated than in unpollinated pistils, particularly in the transmitting tissue.

It is suggested that reduced pollen tube growth in the pistil of the male floral stage of the avocado is associated with the presence of callose.
\end{abstract}

\section{INTRODUCTION}

Avocado (Persea americana Mill.) flowers show marked dichogamy (Robinson and Savage, 1926) and various authors have reported that pollination of the male floral stage does not result in fruit development (Bringhurst, 1952; Peterson, 1956). However, Schroeder (1954) observed that pollen, transferred by direct contact due to the close proximity of the anthers to the stigma in the male floral stage, would germinate and penetrate the stigma. The present study was undertaken to investigate further the behaviour of the pollen tube in the pistil of the male floral stage of the avocado and subsequent fruit retention. 


\section{MATERIALS AND METHODS}

Two- and 3-year-old grafted avocado plants, cultivar 'Fuerte', which had initiated flower buds were placed in growth cabinets maintained at $25^{\circ} \mathrm{C}$ during the day and $20^{\circ} \mathrm{C}$ at night, with a 12 -hour photoperiod and light intensity of 26,000 lux.

The floral cycle under these conditions has been described by Sedgley (1977). The flowers first opened in the afternoon and were in the female stage $(0 \mathrm{~h})$. After closing overnight they re-opened in the male stage the next morning $(18 \mathrm{~h})$. Closure of the male stage was in progress by $24 \mathrm{~h}$, and the flowers then remained closed. All flowers were labelled at $0 \mathrm{~h}$.

Pollen tube growth - (a) Self pollination: Flowers either received no treatment or were emasculated at $0 \mathrm{~h}$. Pistils were collected at $24 \mathrm{~h}$.

(b) Hand pollination: Flowers were pollinated either at $0 \mathrm{~h}$ with pollen which had been collected from flowers in the male stage and stored desiccated at $4^{\circ} \mathrm{C}$ for $6 \mathrm{~h}$ (Schroeder, 1942), or at $18 \mathrm{~h}$ with fresh pollen. All pistils were collected $4 \mathrm{~h}$ after pollination.

Pistils were fixed in Carnoy's fluid at $25^{\circ} \mathrm{C}$ for $18 \mathrm{~h}$, hydrated and softened for $1 \mathrm{~h}$ at $60^{\circ} \mathrm{C}$ in $0.8 \mathrm{~N}$ sodium hydroxide. They were stained with a $0.1 \%$ solution of water soluble aniline blue (George T. Gurr Ltd. Lot No.06604) in $0.1 \mathrm{~N}$ tripotassium orthophosphate for $18 \mathrm{~h}$ (Martin, 1959), and mounted in $80 \%$ glycerol. Preparations were observed using a Zeiss photomicroscope II with reflected light from an HBO 100 super pressure mercury lamp, BG 3 exciter filter and $65 / 50$ barrier filter combination. Pollen tubes were counted as described by Sedgley (1976).

Flower retention. - Flowers were either left unpollinated, pollinated at $0 \mathrm{~h}$ or pollinated at $18 \mathrm{~h}$. Each flower was observed daily and time to abscission noted. The average flower retention time after the 3 treatments was calculated.

Callose localisation - Flowers were either pollinated at $0 \mathrm{~h}$ with stored pollen or left unpollinated. Pistils were collected at $0,18,24$ and $42 \mathrm{~h}$ and fixed either in Carnoy's fluid or $3 \%$ glutaraldehyde in $0.025 \mathrm{M}$ phosphate buffer $\mathrm{pH} 7.0$, both at $25^{\circ} \mathrm{C}$. Aniline blue-stained squashes were prepared as described previously and 50 pistils were collected for each treatment and time period for fixation in Carnoy's fluid, and 6 for each treatment and time period for fixation in glutaraldehyde. A further 12 unpollinated pistils were fixed at $42 \mathrm{~h}$ in glutaraldehyde at $25^{\circ} \mathrm{C}$ : frozen $10-\mu \mathrm{m}$ thick longitudinal sections were obtained from 10 pistils using a cryostat and the other 2 pistils were embedded in glycol methacrylate according to the method of Feder and O'Brien (1968). The glycol methacrylate was removed from $2.25-\mu \mathrm{m}$ thick longitudinal sections with acetone using the method of Bencosme et al. (1959). Sections were mount ed in a $1: 1$ mixture of aniline blue stain and $80 \%$ glycerol in $0.2 \mathrm{M}$ phosphate buffer $\mathrm{pH}$ 8.0. Preparations were observed in ultra violet light as described 
previously. For each treatment, time period and method of preparation involving aniline blue staining, a control specimen received $0.1 \mathrm{~N}$ tripotassium orthophosphate without the stain.

A further 10 pistils per treatment per time period were processed as for aniline blue-squash preparations but were stained for $18 \mathrm{~h}$ with $1.5 \%$ resorcin blue (George T. Gurr Ltd. Lot No.04140) in $50 \%$ ethanol (Reynolds and Dashek, 1976). Preparations were observed using bright field illumination.

\section{RESULTS}

Pollen tube growth. - Pollen tubes were not visible in the pistil of the avocado unless stained with aniline blue or with resorcin blue.

(a) Self pollination: No pollen was present in the emasculated pistils (Table I). Small numbers of pollen tubes were present in the stigma and style, but none in the ovary of the untreated flowers.

(b) Hand pollination: Fewer pollen tubes were present in the pistils of the flowers pollinated at $18 \mathrm{~h}$ than in those pollinated at $0 \mathrm{~h}$ (Table 2). A pollen tube reached the ovary in only 1 pistil pollinated at $18 \mathrm{~h}$ as compared with every pistil pollinated at $0 \mathrm{~h}$.

TABLE 1

Pollen tubes counted in pistils of self-pollinated and emasculated avocado flowers at $24 \mathrm{~h}$

\begin{tabular}{lllll}
\hline & Stigma & Style & Style & $\begin{array}{l}\text { Style and } \\
\text { ovary }\end{array}$ \\
\hline $\begin{array}{l}\text { Distance from } \\
\text { surface of } \\
\text { stigma (mm) }\end{array}$ & $0-0.5$ & $0.5-1.5$ & $1.5-2.5$ & $2.5-3.5$ \\
$\begin{array}{l}\text { Average no. of } \\
\text { tubes per self- } \\
\text { pollinated pistil } \\
\begin{array}{l}110 \text { observa- } \\
\text { tions) }\end{array}\end{array}$ & $5.00 \mp 0.75$ & $1.57 \pm 0.27$ & $0.16 \pm 0.04$ & $0.00 \pm 0.00$ \\
$\begin{array}{l}\text { Average no. of } \\
\text { tubes per } \\
\text { emasculated } \\
\text { pistil (12 } \\
\text { observations) }\end{array}$ & $0.00 \pm 0.00$ & $0.00 \pm 0.00$ & $0.00 \pm 0.00$ & $0.00 \pm 0.00$ \\
\hline
\end{tabular}

Flower retention. - Flowers pollinated at $0 \mathrm{~h}$ were retained on the plant longer than flowers pollinated at $18 \mathrm{~h}$ or unpollinated flowers and there was no difference between the latter 2 treatments (Table 3 ).

Callose localisation. - Callose was not visible in the pistil of the avocado unless stained with aniline blue or with resorcin blue. 


\section{TABLE 2}

Pollen tubes counted in pistils of avocado flowers hand-pollinated at $0 \mathrm{~h}$ (female stage) and $18 \mathrm{~h}$ (male stage)

\begin{tabular}{lllll}
\hline & Stigma & Style & Style & $\begin{array}{l}\text { Style and } \\
\text { ovary }\end{array}$ \\
\hline $\begin{array}{l}\text { Distance from } \\
\text { surface of } \\
\text { stigma (mm) }\end{array}$ & $0-0.5$ & $0.5-1.5$ & $1.5-2.5$ & $2.5-3.5$ \\
$\begin{array}{l}\text { Average no. of } \\
\text { tubes per } \\
\text { pistil pollin- } \\
\text { ated at } 0 \mathrm{~h} \\
\text { (20 observa- } \\
\text { tions) }\end{array}$ & $71.90 \pm 6.35$ & $20.25 \pm 2.12$ & $3.05 \pm 0.34$ & $1.00 \pm 0.00$ \\
$\begin{array}{l}\text { Average no. of } \\
\text { tubes per } \\
\text { pistil pollin- } \\
\text { ated at } 18 \mathrm{~h} \\
\left(\begin{array}{l}110 \text { observa- } \\
\text { tions) }\end{array}\right.\end{array}$ & & & & \\
\hline
\end{tabular}

TABLE 3

Retention of avocado flowers hand-pollinated at $0 \mathrm{~h}$ (female stage) at $18 \mathrm{~h}$ (male stage) and left unpollinated

\begin{tabular}{lll}
\hline Treatment & $\begin{array}{l}\text { Total number of } \\
\text { flowers observed }\end{array}$ & $\begin{array}{l}\text { Average number of } \\
\text { days each flower } \\
\text { retained }\end{array}$ \\
\hline Pollinated at $0 \mathrm{~h}$ & 323 & $9.37 \pm 0.38$ \\
Pollinated at $18 \mathrm{~h}$ & 319 & $3.97 \pm 0.24$ \\
Unpollinated & 357 & $4.32 \pm 0.20$ \\
\hline
\end{tabular}

The occurrence of aniline blue-positive material in the component tissue of the pistil at different times after first opening of the flower is shown in Table 4 , in which nomenclature of pistil tissues follows that of Bell and Hicks (1976). All preparations without aniline blue (Fig. 1) and $0 \mathrm{~h}$ preparations with aniline blue (Fig. 2) fluoresced a pale green colour when observed with ultra violet light. Bright yellow areas of fluorescence occurred in the stigmatic papillae (Figs. 3 and 4), in the transmitting tissue (Figs. 5 and 6), in the vascular tissue (Figs. 5 and 7 ) and in the cortex and epidermis (Figs. 8 and 9) from $18 \mathrm{~h}$ onwards. In all cases the fluorescence was associated with the cell walls (Figs. 


\section{TABLE 4}

Percentage of pistils in which aniline blue-positive material was present in the component tissues

\begin{tabular}{|c|c|c|c|c|c|c|c|c|}
\hline \multirow[t]{3}{*}{ Tissue } & \multicolumn{8}{|c|}{ Time after first opening } \\
\hline & \multicolumn{4}{|c|}{ Unpollinated } & \multicolumn{4}{|c|}{ Pollinated } \\
\hline & $\mathrm{Oh}$ & $18 \mathrm{~h}$ & $24 \mathrm{~h}$ & $42 \mathrm{~h}$ & $\mathrm{Oh}$ & $18 \mathrm{~h}$ & $24 \mathrm{~h}$ & $42 \mathrm{~h}$ \\
\hline $\begin{array}{l}\text { Stigmatic } \\
\text { papillae }\end{array}$ & 0 & 40 & 86 & 100 & 0 & 50 & 92 & 100 \\
\hline $\begin{array}{l}\text { Transmitting } \\
\text { tissue }\end{array}$ & 0 & 0 & 56 & 100 & 0 & 62 & 86 & 100 \\
\hline $\begin{array}{l}\text { Vascular } \\
\text { tissue }\end{array}$ & 0 & 46 & 96 & 100 & 0 & 50 & 88 & 100 \\
\hline $\begin{array}{l}\text { Cortex and } \\
\text { epidermis }\end{array}$ & 0 & 0 & 16 & 100 & 0 & 0 & 20 & 100 \\
\hline
\end{tabular}
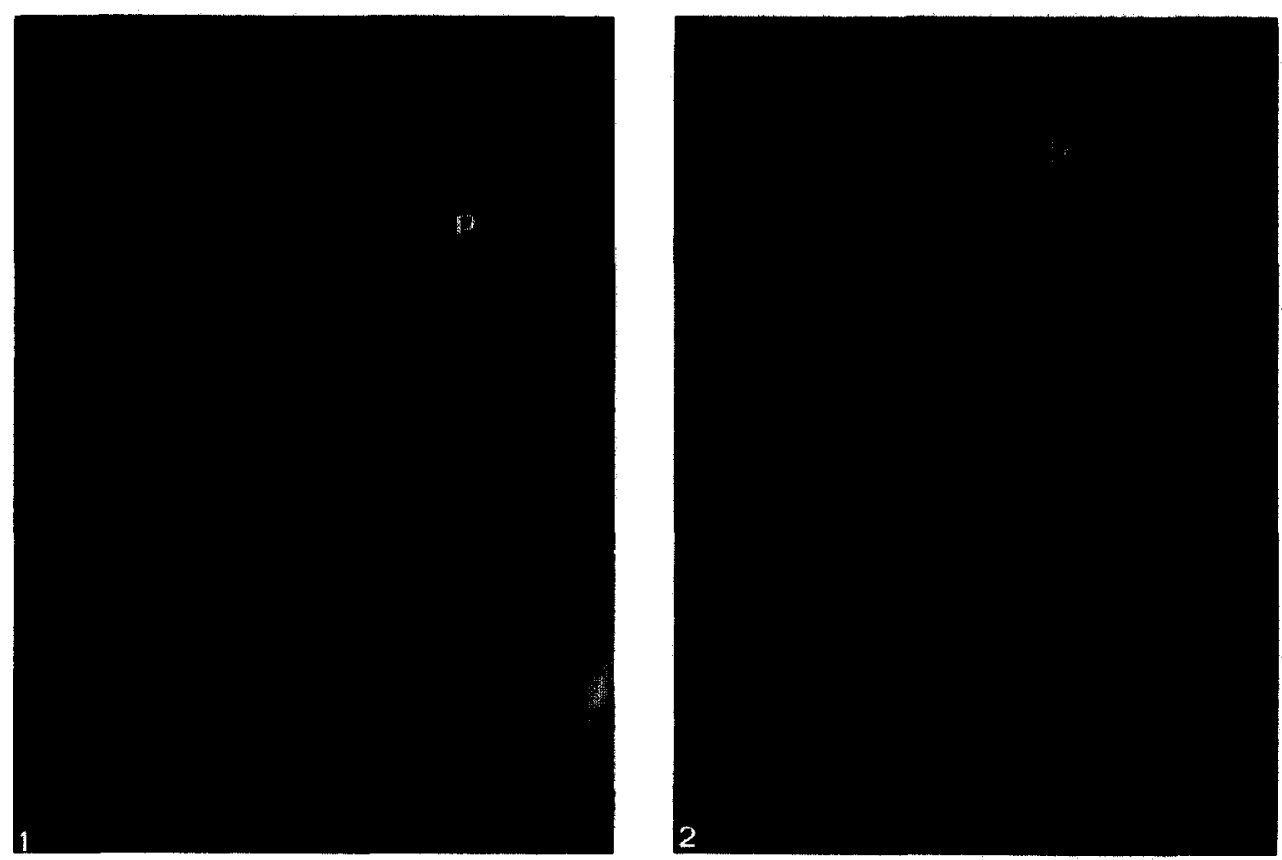

Fig.1. $42 \mathrm{~h}$ unpollinated stigma, $10 \mu \mathrm{m}$ section without aniline blue. $\times 600 . \mathrm{p}=$ papilla cell.

Fig. $2.0 \mathrm{~h}$ unpollinated stigma, squash preparation with aniline blue. $\times 400 . \mathrm{p}=$ papilla cell. 

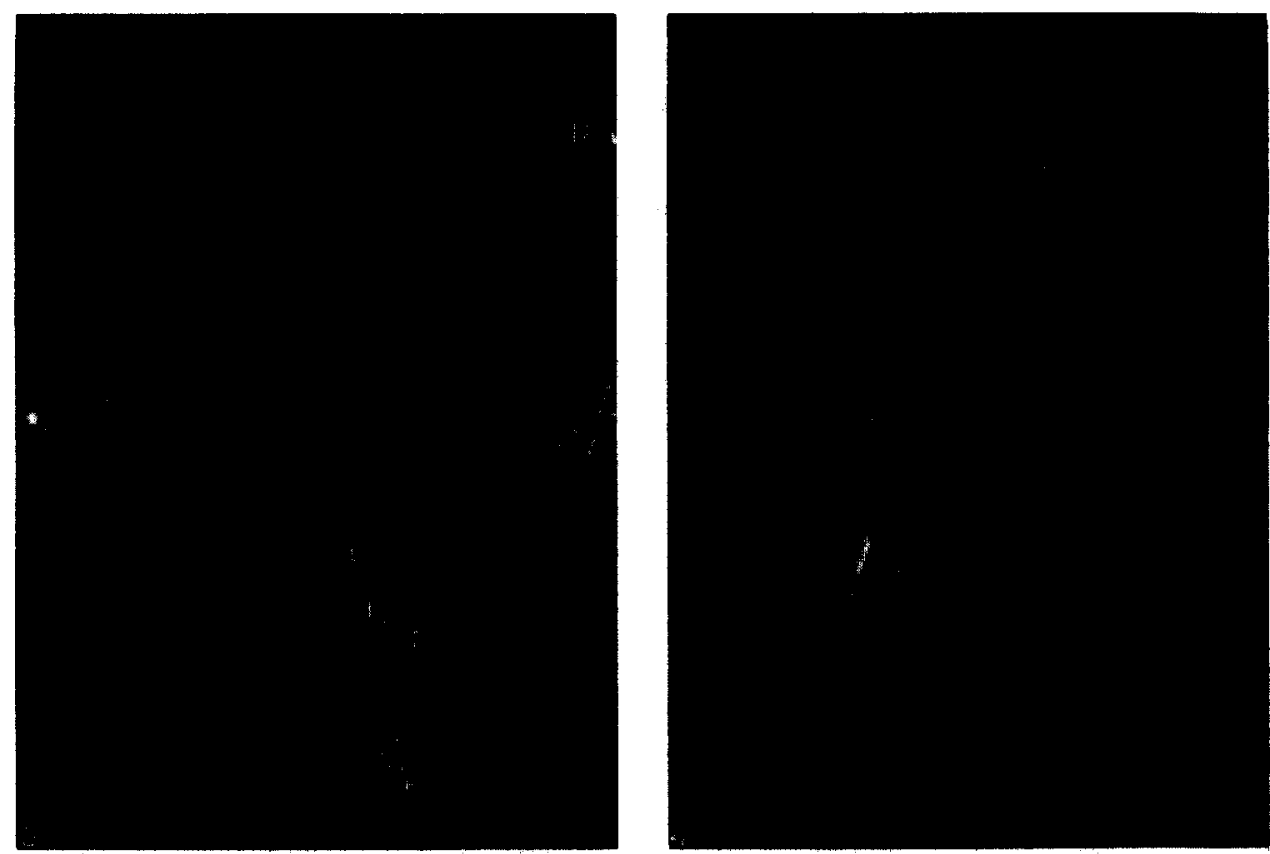

Fig. $3.18 \mathrm{~h}$ unpollinated stigma, squash preparation, with aniline blue. $\times 400 . \mathrm{p}=$ papilla cell.

Fig. $4.42 \mathrm{~h}$ unpollinated stigma, $10 \mu \mathrm{m}$ section with aniline blue. $\times 800 . \mathrm{p}=$ papilla cell; $\mathrm{c}=$ callose.
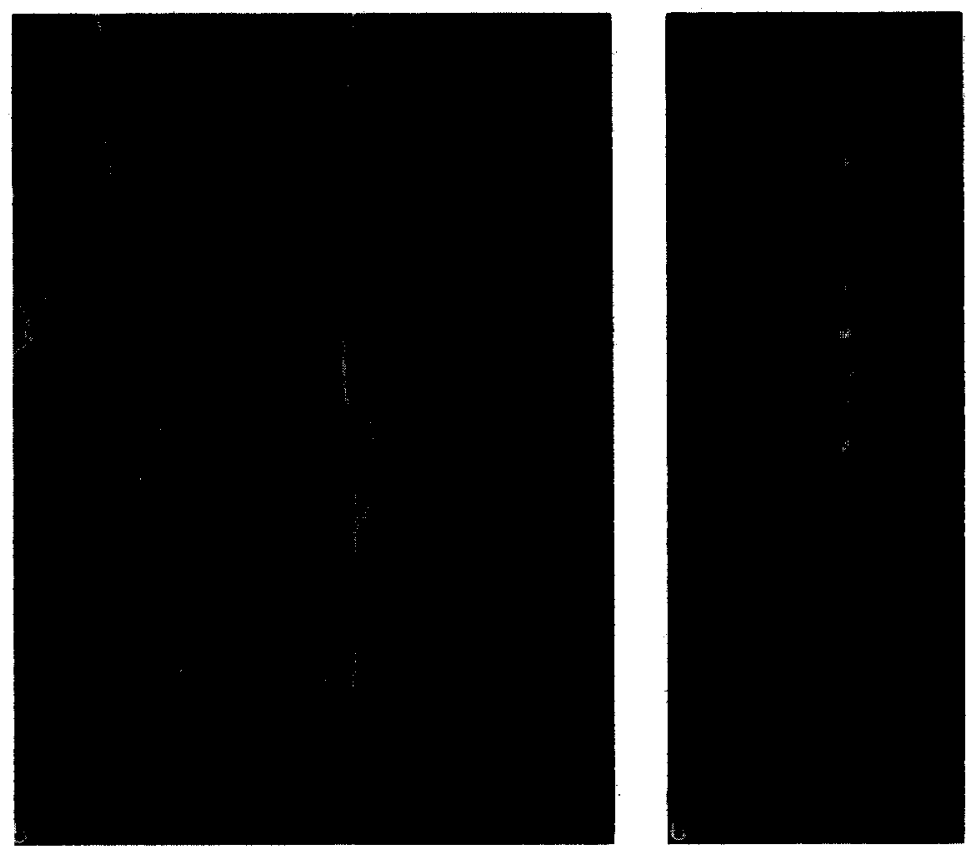

Fig.5. 24 h pollinated style, squash preparation with aniline blue. $\times 75 . \mathrm{pt}=$ pollen tube; $\mathrm{tt}=$ transmitting tissue; $\mathrm{vb}=$ vascular bundle $; \mathrm{h}=$ hair.

Fig. $6.42 \mathrm{~h}$ unpollinated style, squash preparation with aniline blue. $\times 300 . \mathrm{tt}=$ transmitting tissue; $\mathbf{c}=$ callose . 

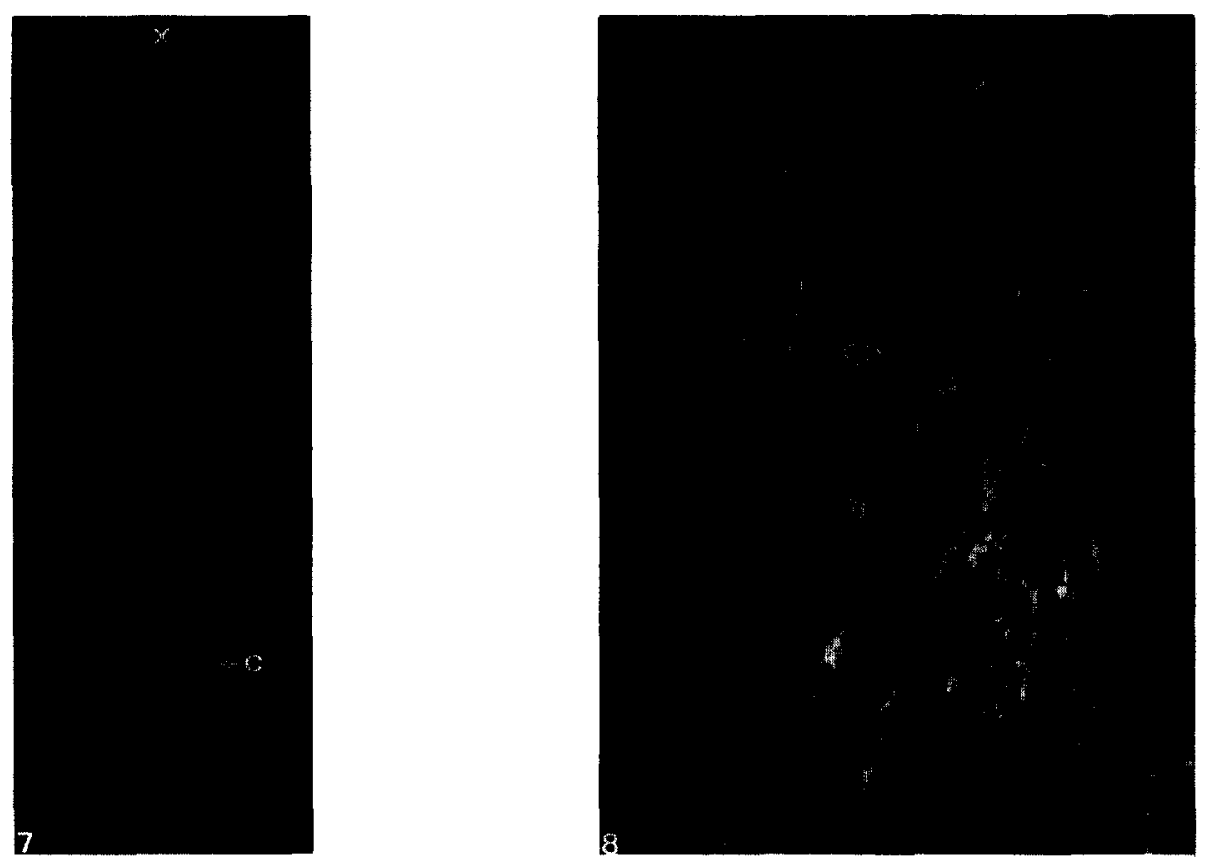

Fig.7. $42 \mathrm{~h}$ unpollinated style, $2.25 \mu \mathrm{m}$ section with aniline blue. $\times 500 . \mathrm{x}=\mathrm{xylem} ; \mathrm{c}=$ callose.

Fig. $8.42 \mathrm{~h}$ pollinated style, squash preparation with aniline blue. $\times 75 . \mathrm{pt}=$ pollen tube; $\mathrm{vb}=$ vascular bundle $; \mathrm{co}=$ cortex $; \mathrm{c}=$ callose $\mathrm{h}=$ hair .

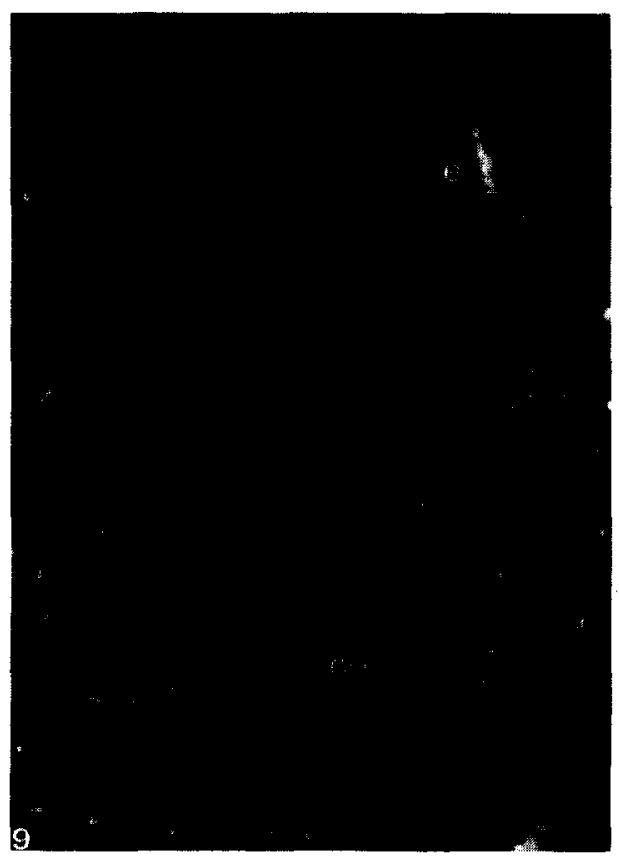

Fig.9. $42 \mathrm{~h}$ unpollinated style, $10 \mu \mathrm{m}$ section, with aniline blue. $\times 500$. e $=$ epidermis; $\mathrm{c}=$ callose $; \mathrm{co}=$ cortex . 


\section{TABLE 5}

Percentage of unpollinated pistils in which resorcin blue-positive material was present in the component tissues

\begin{tabular}{llccc}
\hline Tissue & \multicolumn{4}{l}{ Time after first opening } \\
\cline { 2 - 5 } & $0 \mathrm{~h}$ & $18 \mathrm{~h}$ & $24 \mathrm{~h}$ & $42 \mathrm{~h}$ \\
\hline $\begin{array}{l}\text { Stigmatic } \\
\text { papillae }\end{array}$ & 0 & 30 & 10 & 70 \\
$\begin{array}{l}\text { Transmitting } \\
\text { tissue }\end{array}$ & 0 & 10 & 20 & 70 \\
$\begin{array}{l}\text { Vascular } \\
\text { tissue }\end{array}$ & 0 & 30 & 50 & 80 \\
$\begin{array}{l}\text { Cortex and } \\
\text { epidermis }\end{array}$ & 0 & 0 & 20 & 100 \\
\hline
\end{tabular}

4, 7 and 9). Callose occurred earlier in pollinated than in unpollinated pistils, particularly in the transmitting tissue. There was no difference in the localisation of fluorescence between preparations collected at the same time which were fixed in Carnoy's fluid or glutaraldehyde.

Staining with resorcin blue gave results similar to aniline blue (Table 5) except that the callose stained blue.

\section{DISCUSSION}

Although pollen was transferred by direct contact from the anther to the stigma of the male floral stage as observed by Schroeder (1954), penetration of the ovary by a pollen tube did not occur and there was no flower retention. Fewer grains germinated on the stigma at $18 \mathrm{~h}$ than at $0 \mathrm{~h}$, and of those that did germinate a smaller proportion grew into the style. Thus the failure to set fruit following pollination of the male floral stage is due, at least in part, to reduced pollen germination and tube growth.

Both aniline blue and resorcin blue have been described as stains for callose (Currier, 1957; Eschrich, 1956), which is a $\beta-1,3$-glucan (Kessler, 1958). However, the physicochemical basis for the staining has not been established (Clarke and Stone, 1963) and Reynolds and Dashek (1976) reported consistent staining of pollen tube walls with lacmoid blue (an analogue of resorcin blue) but not with aniline blue. The two stains used in the present study both gave the same staining pattern and the aniline blue fluorochrome gave more consistent results.

Callose is generally considered to form a barrier as in wounded tissue where it plugs the damaged area (Currier, 1957). Jensen and Fisher (1969) reported its deposition in the transmitting tissue of Gossypium hirsutum after passage 
of the pollen tubes, as described here in avocado. They suggested that the passage of the tubes changed the permeability of the cells and that the callose was formed as a wound response to prevent cell leakage. Callose occurs around developing pollen (Heslop-Harrison, 1964) and embryosacs (Rodkiewicz, 1973) where it is considered to provide a molecular filter, allowing nutrients to pass but not larger molecules which may interfere with the autonomy of the developing gametophytes. The deposition of callose has also been described in the stigma of flowers with sporophytic self-incompatibility mechanisms such as Raphanus sativus (Dickinson and Lewis, 1973). In this case the callose was deposited on the wall of the papilla cell as a result of incompatible pollination and blocked penetration of the stigma by the pollen tube.

In the avocado, reduced pollen tube growth in the pistil of the male floral stage coincided with the appearance of aniline blue-positive and resorcin blue-positive material associated with the cell walls of the component tissues. It is suggested that the presence of callose in the pistil of the avocado may reduce the availability to the pollen of substances necessary for germination and tube growth and thus contribute to the female sterility of the male floral stage.

\section{ACKNOWLEDGEMENTS}

I wish to thank Mr. D. McE. Alexander for providing the grafted 'Fuerte' plants and Ms. L. Kramm for technical assistance.

\section{REFERENCES}

Bell, J. and Hicks, G., 1976. Transmitting tissue in the pistil of tobacco: light and electron microscopic observations. Planta, 131: 187-200.

Bencosme, S.A., Stone, R.S., Latta, H. and Madden, S.C., 1959. A rapid method for localisation of tissue structures or lesions for electron microscopy. J. Biophys. Biochem. Cytol., 5: 508-509.

Bringhurst, R.S., 1952. Sexual reproduction in the avocado. Calif. Avocado Soc. Yearb., 1952: 210-214.

Clarke, A.E. and Stone, A.B., 1963. Chemistry and biochemistry of $\beta-1,3$-glucans. Rev. Pure Appl. Chem., 13: 134-156.

Currier, H.B., 1957. Callose substance in plant cells. Am. J. Bot., 44: 478-488.

Dickinson, H.G. and Lewis, D., 1973. Cytochemical and ultrastructural differences between intraspecific compatible and incompatible pollinations in Raphanus. Proc. R. Soc. London, Ser. B., 183: 21-38.

Eschrich, W., 1956. Kallose (Ein kritischer sammelbericht). Protoplasma, 47: 387-530.

Feder, N. and O'Brien, T.P., 1968. Plant microtechnique: some principles and new methods. Am. J. Bot., 55: 123-142.

Heslop-Harrison, J., 1964. Cell walls, cell membranes and protoplasmic connections during meiosis and pollen development. In: H.F. Linskens (Editor), Pollen Physiology and Fertilisation. North Holland, Amsterdam, pp. 39-47.

Jensen, W.A. and Fisher, D.B., 1969. Cotton embryogenesis: the tissues of the stigma and style and their relation to the pollen tube. Planta, 84: 97-121.

Kessler, G., 1958. Zur charakterisierung der Siebröhrenkallose. Ber. Schweiz. Bot. Ges., 68: $5-43$. 
Martin, F.W., 1959. Staining and observing pollen tubes in the style by means of fluorescence. Stain Technol., 34: 125-128.

Peterson, P.A., 1956. Flowering types in the avocado with relation to fruit production. Calif. Avocado Soc. Yearb., 1956: 174-179.

Reynolds, J.D. and Dashek, W.V., 1976. Cytochemical analysis of callose localisation in Lilium longiflorum pollen tubes. Ann. Bot., 40: 409-416.

Robinson, T.R. and Savage, E.M., 1926. Pollination of the avocado. U.S.D.A. Circ., 387: $1-16$.

Rodkiewicz, B., 1973. Callose walls in megaspores in Fuchsia and Epilobium. Carylogia, 25 (Suppl.): 59-66.

Schroeder, C.A., 1942. Pollen germination in the avocado. Proc. Am. Soc. Hortic. Sci., 41: $181-182$.

Schroeder, C.A., 1954. Some aspects of pollination in the avocado. Calif. Avocado Soc. Yearb., 1953-54: 159-162.

Sedgley, M., 1976. Control by the embryosac over pollen tube growth in the style of the avocado (Persea americana Mill.). New Phytol., 77: 149-152.

Sedgley, M., 1977. The effect of temperature on floral behaviour, pollen tube growth and fruit set in the avocado. J. Hortic. Sci., 52: 135-141. 